\title{
Abiotrophia defectiva
}

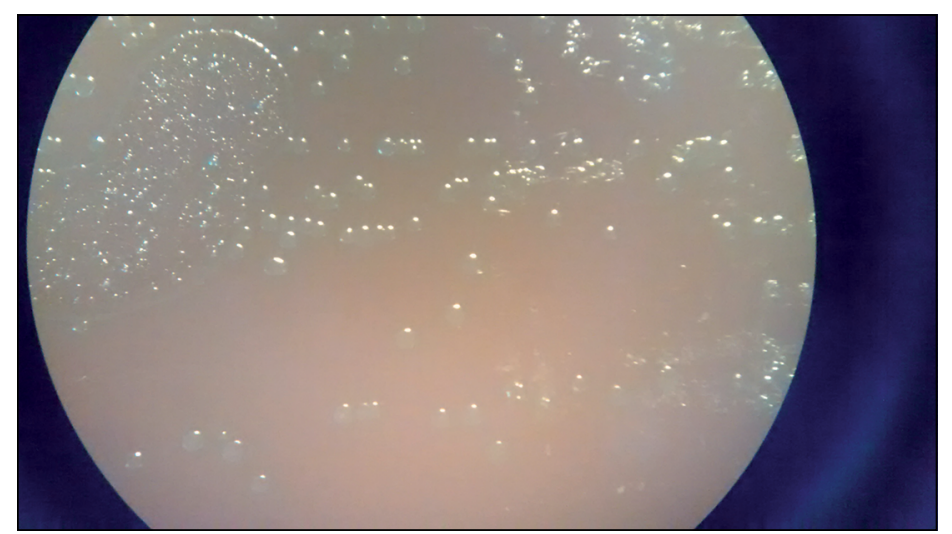

Figura 1. Colonias de Abiotrophia defectiva en agar chocolate observadas con lupa estereoscópica.

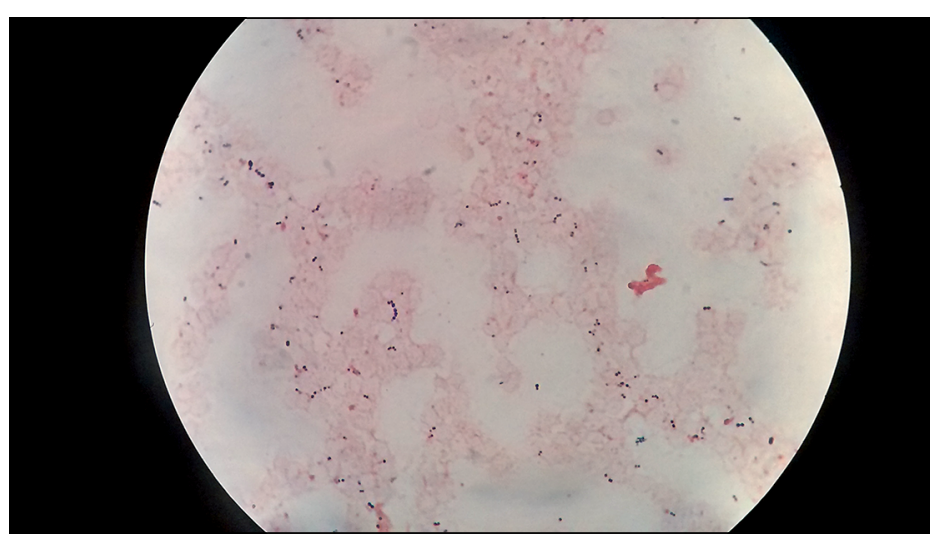

Figura 2. Tinción de Gram de muestra de hemocultivo con presencia de $A$. defectiva.

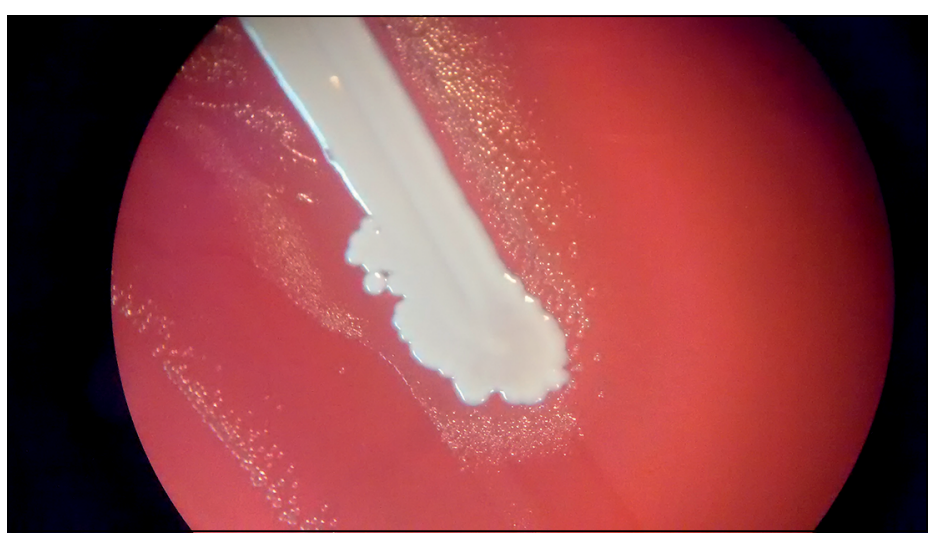

Figura 3. Satelitismo alrededor de Staphylococcus aureus en agar sangre de cordero $5 \%$. 


\section{Abiotrophia defectiva}

Abiotrophia era considerado parte del grupo de variantes nutricionales de Streptococcus spp. (SNV). En 1995 se creó el género Abiotrophia, en que se incluyeron las especies, A. defectiva, A. adiacens, A. elegans y para-adiacens. El año 2000 se propone un nuevo género, Granulicatella y se reclasifican quedando entonces el género Abiotrophia sólo con una especie: $A$. defectiva.

Es una cocácea, anaerobia facultativa, inmóvil, catalasa negativa, generalmente alfa hemolítica. Se presenta como cocos grampositivos dispuestos en pares o cadenas, aunque también pueden observarse pleomórficos y gram variables cuando se desarrollan bajo condiciones nutritivas subóptimas. Crece en medios enriquecidos, no selectivos, como agar chocolate y agar Brucella con 5\% sangre de caballo, pero no en agar sangre de cordero 5\% (Figuras 1 y 2). Característicamente muestran crecimiento en "satelitismo", alrededor de colonias de Staphylococcus u otros microorganismos si se encuentra en un medio que no le aporta los factores nutritivos que requiere para su desarrollo (Figura 3). También se puede favorecer su crecimiento con suplementos de piridoxal (en discos comerciales o en solución acuosa con concentración final de $0,001 \%$ ). Otras características fenotípicas son reacción PYR y LAP positivas, la producción de $\alpha$ y $\beta$ galactosidasa y $\beta$ glucuronidasa negativa.

Para la identificación, el uso de técnicas moleculares mediante secuenciación es el estándar de oro. Se han reportado resultados variables con el uso de galerías de pruebas miniaturizadas y de los sistemas automatizados comerciales, por lo que la espectrometría de masas parece ser actualmente la mejor herramienta disponible para los laboratorios clínicos.

Es parte de la microbiota de la cavidad bucal, y ha sido descrito como agente de endocarditis de válvulas nativas y protésicas, infecciones oftálmicas, del sistema nervioso central y otras asociadas a dispositivos protésicos.

El estudio de susceptibilidad se debe realizar por método de microdilución en caldo, con medio Mueller-Hinton suplementado con sangre y piridoxal, empleando los puntos de corte definidos por el CLSI. El testeo primario debe incluir penicilina, cefalosporinas de tercera generación y vancomicina. Algunos estudios han reportado que $A$. defectiva tiene una alta resistencia a penicilina, manteniendo una buena susceptibilidad a cefalosporinas de tercera generación y vancomicina, y no se ha descrito resistencia de alto nivel a aminoglicósidos. Se ha demostrado un efecto sinérgico entre agentes $\beta$ lactámicos y aminoglicósidos.

\section{Referencias bibliográficas}

1.- Bouvet A, Grimont F, Grimont P A D. Streptococcus defectivus sp nov and Streptococcus adjacens sp nov., nutritionally variant streptococci from human clinical specimens. Int J Syst Bacteriol 1989; 39: 290-4.

2.- Christensen J J, Facklam R R. Granulicatella and Abiotrophia species from human clinical specimens. J Clin Microbiol 2001; 39: 3520-3.

3.- Alberti M O, Hindler J A, Humphries R M. Antimicrobial susceptibilities of Abiotrophia defectiva, Granulicatella adiacens and Granulicatella elegans. Antimicrob Agents Chemother 2016; 60: 1411-20.

4.- CLSI. Methods for antimicrobial dilution and disk susceptibility Testing of Infrequently Isolated or Fastidious bacteria. Approved Guideline. Second edition. CLSI document M45-A2. Wayne, PA: Clinical and Laboratory Standards Institute; 2010.

Pamela Rojas, Paulina Castillo y Emma Sepúlveda. Laboratorio de Microbiología, Hospital Padre Alberto Hurtado, Santiago. 